\title{
OZNACZENIA LITEROWE SAMOGŁOSEK W RÓŻNYCH RODZAJACH PISMA DRUKOWANEGO Z XVII WIEKU (NA PODSTAWIE SŁONECZNIKA JEREMIASZA DREXELIUSA)
}

\author{
ANNA SAWA \\ Uniwersytet Marii Curie-Skłodowskiej \\ annasawa@poczta.onet.pl
}

\begin{abstract}
Letter Markering of Vowels in Different Types of Printed Writing from XVII century (on the basis of Slonecznik by Jeremiasz Drexelius)

Slonecznik by Jeremiasz Drexelius was published in 1630. It was the first book printed in Pawel Konrad's local printing house. In the composition of the text, there have been used three kinds of printed writing: schwabacher, italics and antique. The article presents ways of writing vowels in the excerpts of text that were composed with those types of writing. The excerpts provide documentation for variance and prescriptiveness in orthography of the time.
\end{abstract}

Keywords: antique book, spelling, letter, vowel, printed writing

Słowa kluczowe: starodruk, pisownia, litera, samogłoska, pismo drukowane

Pierwszą wydaną w Lublinie polskojęzyczną książką był Słonecznik Jeremiasza Drexeliusa [Drexelius 1630; Estreicher 1897: 317]. Został on wydrukowany w oficynie Pawła Konrada, która była pierwszą polską drukarnią funkcjonującą w tym mieście. O jej założycielu nie zachowały się żadne informacje, nie jest znane jego miejsce urodzenia i nie wiadomo, skąd przybył do Lublina. Można przypuszczać, że zmarł on w 1636 roku, ponieważ począwszy od tej daty, druki 
wydawane w oficynie lubelskiej były sygnowane przez jego żonę, która podpisuje się na nich jako wdowa [Juda 2000: 332-336].

Stonecznik został opublikowany w 1630 roku jako przekład z języka łacińskiego. Autorem łacińskiego tekstu książki był Jeremiasz Drexelius, niemiecki jezuita żyjący w latach 1581-1638 [Grzebień 1985: 209]. Książki autorstwa Drexeliusa miały w XVII wieku około 160 łacińsko- i 40 niemieckojęzycznych wydań - ogółem osiągając nakład od 250000 do 300000 egzemplarzy [Kemper 1985: 163]. Przekładano je na język francuski, włoski, flamandzki, czeski, angielski i polski [Valentin 1985: 180]. Lubelska edycja Stonecznika była pierwszym wydaniem tego dzieła w Polsce. Autorem tłumaczenia na język polski był Albrycht Stanisław Radziwiłł.

Popularność Drexeliusa w czasie trwania reform potrydenckich dawała Pawłowi Konradowi nadzieję na uzyskanie znacznych dochodów ze sprzedaży książki. Sam Stonecznik doczekał się w Polsce później jeszcze jednego wydania ${ }^{1}$, wytłoczonego w Krakowie u Łukasza Kupisza [K. Estreicher 1897: 317]. Również inne dzieła Drexeliusa były chętnie wydawane i nabywane. Renata Żurkowa [1986: 77-78] wspomina o obecności książek, jako literatury religijnej, w księgozbiorach mieszczan krakowskich. Elżbieta Torój [1997: 142, 146] odnotowała z kolei tekst Stonecznika w bibliotekach lublinian.

Pełny tytuł interesującego mnie dzieła brzmi: Stonecznik Albo Porownanie Woli Ludzkiey z wola Bożą. Książka podejmowała tematykę religijno-moralną i została zadedykowana królewnie Annie Katarzynie, córce Zygmunta III Wazy. Dedykacja dla Anny Katarzyny z jednej strony wiązała się z pozycją Albrychta Stanisława Radziwiłła na dworze królewskim [Przyboś, Żelewski 1980: 5-86], z drugiej strony wymuszała na drukarzu starania o wysoki poziom wydawniczy książki [Dziok-Strelnik 1997: 23].

\section{Pisma drukowane w lubelskiej edycji Słonecznika}

Lubelskie wydanie Stonecznika jest obszernym, liczącym 349 stron drukiem. Przeważająca część tekstu została wydrukowana szwabachą. Ten rodzaj pisma² pojawił się w Polsce w 1492 roku, nie miał on jeszcze jednak cech klasycznej szwabachy. Trzydzieści lat później zaczął go używać Florian Ungler, początkowo jako pisma nagłówkowego, później jako tekstowego. Wykorzystywana

\footnotetext{
${ }^{1}$ Bibliografia polska Estreichera podaje informację również o trzeciej edycji, jednak jej istnienie jest wątpliwe [por. Estreicher 1897: 315-318].

2 Za Marią Judą odróżniam rodzaj i krój pisma. Rodzaj pisma to termin nadrzędny wobec określenia krój [Juda 2001].
} 
przez niego szwabacha miała już klasyczną formę. W 1527 roku Ungler wprowadził do użytku zmodernizowaną wersję szwabachy, która była wynikiem próby dostosowania tegoż pisma do potrzeb druku w języku polskim, co jednak nie powiodło się. Szwabacha znajdowała się też w kasztach, m.in. Aleksandra Augezdeckiego, Łazarza Andrysowicza, Macieja Wirzbięty i Jana Januszowskiego. Upowszechniła się w drukarniach całej Polski i funkcjonowała w polskim drukarstwie jeszcze w XVIII wieku. Stosowano ją jako pismo tekstowe, nagłówkowe i komentarzowe, głównie do składu tekstów w języku polskim i niemieckim. Szwabacha wykazywała pewne związki z pismem odręcznym, jednak zastosowanie technik drukarskich pozwoliło na uzyskanie największej, spośród pism postgotyckich, czytelności [Juda 2001: 98-113].

Ilustracja 1. Fragment tekstu Słonecznika złożony szwabachą [Drexelius 1630: 2; źródło: skan BC UMCS]

\begin{tabular}{|c|}
\hline 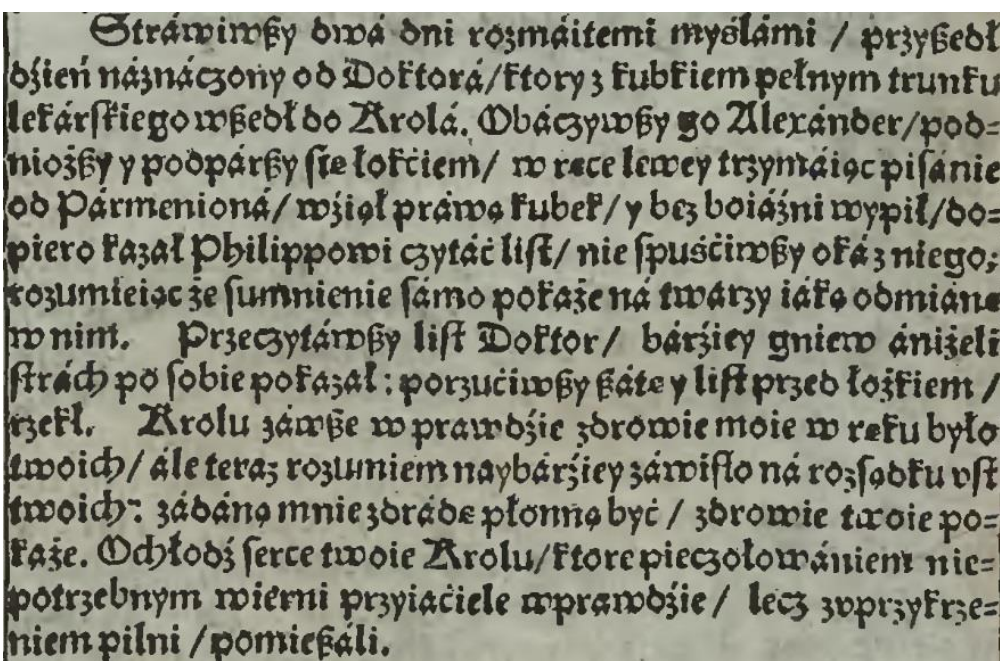 \\
\hline
\end{tabular}

Obszerny list dedykacyjny, zamieszczony w Słoneczniku, złożono kursywą, podobnie jak podtytuły kolejnych rozdziałów i podrozdziałów, marginalia oraz fragmenty tekstu na stronie tytułowej. Było to zgodne z ówczesną praktyką wydawniczą, w której kursywa odgrywała rolę pisma tekstowego, nagłówkowego i komentarzowego. Kursywa drukowana została zaprojektowana z myślą o wydawaniu krytycznych edycji tekstów starożytnych. Pismo to pojawiło się w Polsce w 1523 roku w oficynie drukarskiej Hieronima Wietora. Początkowo wykorzystywano ją do druku łacińskich utworów poetyckich, później do dzieł naukowych z zakresu 
filozofii, teologii, patrystyki i łacińskich utworów polskich autorów. Z biegiem czasu zaczęto składać nią też odrębne fragmenty książek, takie jak: przedmowy, listy dedykacyjne, teksty przywilejów drukarskich i nagłówki [Juda 2001: 219-221].

Ilustracja 2. Fragment tekstu Słonecznika złożony kursywą [Drexelius 1630: 2; źródło: skan BC UMCS]

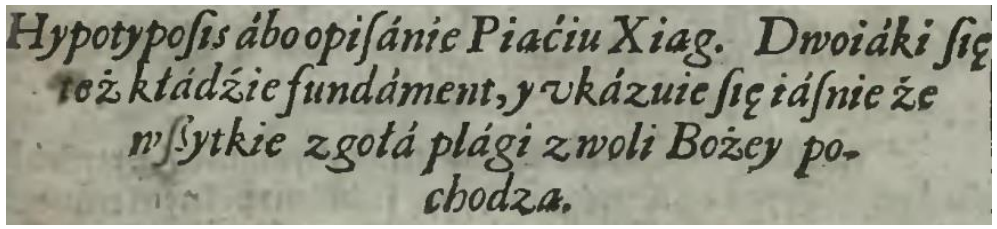

Antykwa występowała w Słoneczniku sporadycznie, ponieważ zgodnie ze zwyczajami drukarzy tego okresu, używano jej głównie do wydawania tekstów w języku łacińskim [Juda 2001: 154-188]. Pojedyncze czcionki antykwowe posiadała już Drukarnia Kazań papieża Leona I funkcjonująca w drugiej połowie XV wieku we Wrocławiu lub Chełmnie ${ }^{3}$. Cały komplet antykwy pojawił się w Polsce w drukarni Floriana Unglera i Wolfganga Lerna. W XVI wieku antykwa (różnej proweniencji) występowała $w$ warsztatach typograficznych na terenie całej Polski. Była pismem przeznaczonym do składu łacińskojęzycznych tekstów, początkowo literackich, później również dzieł z innych dziedzin. Istniała także praktyka składania jednej książki różnymi rodzajami pisma, w zależności od tego, w jakim języku były napisane poszczególne fragmenty, np. jeśli większość tekstu była napisana w języku polskim składano ją szwabachą, a wstawki w języku łacińskim antykwą4. Antykwa odgrywała również rolę pisma nagłówkowego i niekiedy komentarzowego. Długo nie była używana do składu tekstów w języku polskim, choć nadawała się do tego lepiej niż szwabacha. W latach siedemdziesiątych XVI wieku zaczęła pojawiać się w zapisie wyrazów w języku polskim na stronie tytułowej, później w polskojęzycznych przedmowach, a pod koniec lat sześćdziesiątych XVII wieku w całym tekście książki [Juda 2001: 154-188, 216-221].

\footnotetext{
3 Nie jest znane nazwisko drukarza, spory budzi również miejsce powstania jego druków [por. Szandorowska 1968: 23-49, Lewicka-Kamińska 1973: 495-561, Szandorowska 1991: 37-52]. 4 Takie rozwiązanie graficzne zostało zastosowane w lubelskim wydaniu Słonecznika.
} 
Ilustracja 3. Fragment tekstu Słonecznika złożony antykwą [Drexelius 1630: 3 nlb.; źródło: skan BC UMCS]

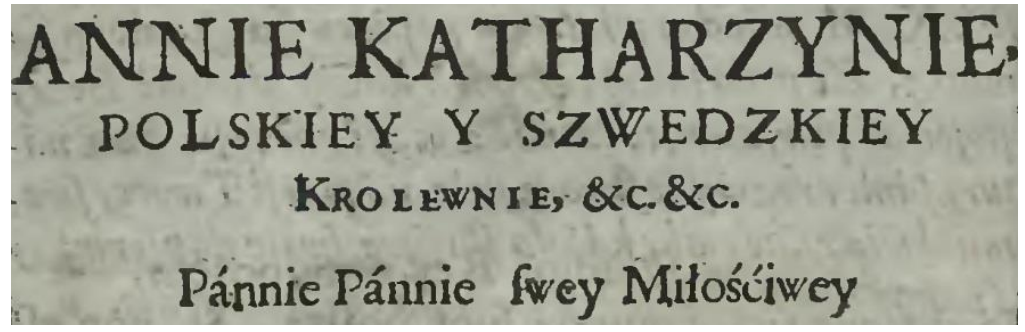

Badacze uważają, że od początku funkcjonowania drukarni lubelskiej używane w niej czcionki były nieco zużyte i niezbyt starannie odlane [Juda 2000: 335].

\section{Metoda i stan badań}

W prowadzonych analizach dążę do porównawczej rekonstrukcji tendencji ortograficznych w trzech rodzajach pisma, używanych do składu tekstu Słonecznika. W tym celu zbadałam pisownię pierwszych pięciu stron Słonecznika złożonych danym pismem, tj. szwabachą, kursywą i antykwą. Analiza takiej objętości tekstu, pozwoliła na zbadanie zdecydowanej większości zasobu typograficznego, jakim dysponował Paweł Konrad do zapisu głosek języka polskiego. Przyjęta miara pięciu stron tekstu do analizy wynika z ustaleń bibliologów, którzy zauważają, że zecer dysponował taką ilością materiału typograficznego, który wystarczał mu do złożenia około pięciu stron tekstu ${ }^{5}$. Pewnym utrudnieniem były duże dysproporcje w objętości tekstu złożonego poszczególnymi rodzajami pisma, co nie odbiegało od ówczesnej praktyki wydawniczej. Taki stan rzeczy wymusił przeglądanie całej książki, w celu znalezienia odpowiedniej próby tekstowej. Miało to miejsce szczególnie w odniesieniu do fragmentów złożonych antykwą, ponieważ są one bardzo krótkie i rozproszone ${ }^{6}$. Pewne trudności wynikały również z zastosowania poszczególnych pism, tzn. pełnionej przez nie funkcji pisma wyróżniającego lub tekstowego. W związku z tym nie zawsze udało się (mimo powiększania próby badawczej) znaleźć przykłady

\footnotetext{
5 Informację tę zawdzięczam prof. dr hab. Marii Judzie. Opis procesu składania tekstu i druku zob. np. J. Pirożyński [2002: 57].

${ }^{6}$ Można sądzić, że Paweł Konrad posiadał komplet czcionek antykwowych ponieważ w 1630 roku wydrukował nimi książkę po łacinie [Dziok-Strelnik 1997: 311-312].
} 
liter majuskulnych w śródgłosie i wygłosie wyrazów składanych szwabachą oraz kursywą, ponieważ pisma te zasadniczo odgrywały rolę pism tekstowych.

Przedmiotem moich szczegółowych obserwacji jest tylko sposób zapisu samogłosek we wspomnianym już Stoneczniku Drexeliusa.

Systematyczne badania językoznawcze relacji między rodzajem pisma a ortografią tekstu drukowanego nie były w zasadzie podejmowane. Autorzy opracowań historycznojęzykowych, w tym także autor Losów polskiej ortografii [Jodłowski 1979], zazwyczaj uogólniają swoje spostrzeżenia i nie uwzględniają $\mathrm{w}$ analizach rodzaju pisma drukowanego, jakim złożono tekst. Można niekiedy spotkać wzmianki na temat znaków diakrytycznych, które nie były dodawane do majuskuł, a występujących przy minuskułach [Burzywoda 2002: 27]. Do rzadkości należą informacje, które wiążą pisownię danej głoski z rodzajem pisma drukowanego - pojawiają się one tylko sporadycznie w artykule Ireny Bajerowej i Anny Wieczorkowej [1989: 14-15] i dotyczą, np. sposobu realizacji głoski $s$ w szwabasze i w antykwie. Wspomniane badaczki odnotowują też brak znaków diakrytycznych przy literach majuskulnych. Zagadnienia związku rodzaju pisma z ortografią nie porusza też Władysława Książek-Bryłowa w artykule dotyczącym języka druków lubelskich [1976: 337-355]. O grafii pierwszych tekstów drukowanych w języku polskim pisał Tomasz Lisowski [2001]. Określił on realizację grafemu w poszczególnych rodzajach pisma drukowanego jako „wariant stylistyczny grafemu, którego zasięg użycia jest regulowany indywidualnymi upodobaniami estetycznymi”, i nadał mu miano alografu fakultatywnego sekundarnego (pobocznego) [Lisowski 2001: 17]. W analizach zapisu poszczególnych głosek badacz nie stosował jednak rozróżnienia na poszczególne rodzaje pism drukowanych. W ostatnich latach problematyką grafii tekstów drukowanych zajmowała się Anetta Luto-Kamińska [2012], która zauważyła, że wiedza na temat panującego w drukarni zwyczaju oznaczania samogłosek może pomóc w interpretacji tekstu. Najnowsze ujęcie ukazujące relacje między techniką drukarską a zapisem wybranych fonemów XVI-wiecznej polszczyzny można znaleźć w pracy Marka Osiewicza [2013].

\section{Kreskowanie samogłosek pochylonych}

W drukach z XVI wieku odróżniano samogłoski pochylone od samogłosek jasnych, kreskując $e$ i o pochylone oraz a jasne. Była to główna zasada, od której oczywiście zdarzały się odstępstwa. Z punktu widzenia moich badań najistotniejsze jest to, że zasadniczo starano się odróżniać $a$ jasne od a pochylonego [Kamińska 1953: 22-23]. Urszula Burzywoda [2002: 28-29], autorka rozdziału dotyczącego 
ortografii w pracy Polszczyzna XVII wieku, stwierdza, że w XVII stuleciu kreskowano $a$ jasne, zanikał z kolei zwyczaj oznaczania $e$ oraz o pochylonego, choć np. Knapiusz zalecał graficzne odróżnianie głosek jasnych i pochylonych.

Analizowany przeze mnie tekst Słonecznika wskazuje, że zwyczaje w zakresie kreskowania samogłosek, panujące w drukarni Pawła Konrada nie różniły się zasadniczo od praktyki obowiązującej w innych oficynach. Kreskowaniu podlegało minuskulne a jasne, bez względu na rodzaj pisma użytego do składu, np.

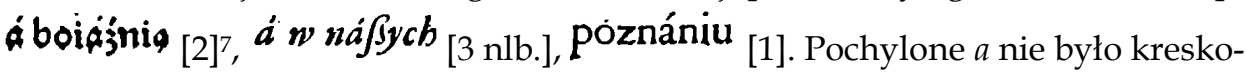
wane, np. కoromia [1], kniat [4 nlb.] $]^{8}$. Znak diakrytyczny zarówno w szwabasze, jak i w antykwie przybierał postać ukośnej kreseczki umieszczonej nad literą, np. rólumer [1], Doftorá [2], porownániu [49]. W kursywie znak ten kształtem zbliżał się do przecinka, np. świáká [3 nlb.],kräiách [3 nlb.].

Duża litera w zapisie $a$ jasnego nie miała znaku diakrytycznego i nie różniła się od zapisu a pochylonego, np. 2ute\{ [4], A potym [5], PIER WSZA [1].

Litera oznaczająca $o$ pochylone nie była kreskowana w żadnym z pism, tak

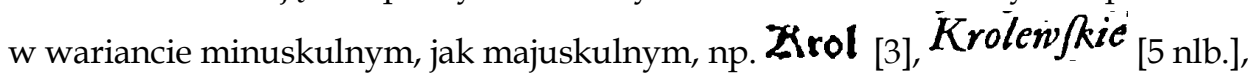

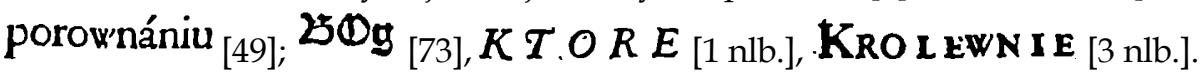

Nie odróżniano literowo również e pochylonego i jasnego, np. $\mathbf{y} \mathbf{r}_{\mathbf{3}}^{\wedge} \mathbf{e} \mathbf{b}$ [6] _Kzcce [1], Jnego [4 nlb.] - Pánie [2 nlb.], fwey [3 nlb.] - Pánnie [3 nlb.] ${ }^{9}$.

Żadna z prawidłowości dotyczących zapisu głosek $a$, o oraz $e$ nie wykazuje związku z pozycją danej głoski w wyrazie i jej otoczeniem fonetycznym.

\section{Zapis samogłosek nosowych}

Już w XVI wieku różnicowano w druku zapisy samogłosek nosowych. Zasada ta była kontynuowana również w XVII stuleciu [Burzywoda 2002: 29]. W Słoneczniku samogłoska $a$ jest oznaczana czcionką $a$ ze znakiem diakrytycznym - zasada

\footnotetext{
7 Liczby w nawiasach oznaczają numery stron $\mathrm{w}$ starodruku. Ponieważ numeracją są w oryginale objęte tylko strony zawierające tekst główny, numeracja strony tytułowej, strony drugiej i stron zawierających dedykację pochodzi ode mnie (zaznaczam wówczas w nawiasie, że strony te nie są liczbowane - nlb.).

8 Brak odpowiednich przykładów w tekście złożonym antykwą.

${ }^{9}$ Znalezienie takich paralelizmów w przypadku liter majuskulnych jest trudne ze względu na ograniczony zasięg użycia wielkich liter w tekście.
} 
ta bezwyjątkowo występuje w minuskulnych literach szwabachy, kursywy i antykwy, np. Drac [1], frois [1], krag [3 nlb.], napierw/sa [4 nlb.], chcacey [149], wola [1 nlb.]. Litery majuskulne nie zawsze są opatrzone znakiem diakrytycznym - $\mathrm{z}$ takim przypadkiem mamy do czynienia $\mathrm{w}$ czcionkach antykwowych, w których $a$ jest oznaczane identycznie jak $a$, np. PIA T A (piąta) [37], co nie jest jednak regułą, ponieważ spotkać też można zapis PI A T A [204]. Majuskulne antykwowe $q$ występuje jednak tylko dwa razy, więc trudno jednoznacznie stwierdzić, czy zróżnicowanie zapisu wynika ze świadomego działania, czy jest błędem drukarskim. W odniesieniu do szwabachy i kursywy nie można poczynić żadnych spostrzeżeń, ponieważ pismami tymi nie złożono fragmentów tekstu zawierających majuskulne $a^{10}$.

W przypadku litery $\varrho$ należy stwierdzić, że $\mathrm{w}$ analizowanym materiale pojawiły się głównie zapisy liter minuskuły. Każdy komplet pisma był w nie wyposażony, o czym świadczą, m.in. zapisy: toòiecy [2], woiáre [2], ízzykiem [1 nlb.], fię [3 nlb.], Gį [149] ${ }^{11}$. Jedyne majuskulne $e$ znalazłam w tekście złożonym antykwą w wyrazie X IE G A [1]. Jego pojawienie się (tak samo jak przytoczony przykład majuskulnego a) jest motywowane faktem, że wielkich liter antykwy używano do wyróżniania poszczególnych elementów tekstu, np. do zapisu liczebników numerujących rozdziały, czy zapisu ich tytułów.

We fragmentach tekstowych złożonych kursywą i szwabachą znajdują się wyrazy o identycznym rdzeniu, ale różnej pisowni samogłosek nosowych ${ }^{12}$. W kursywie: Foftempuie [3 nlb.], przyftempu [5 nlb.], poftempuie/s [5 nlb.],

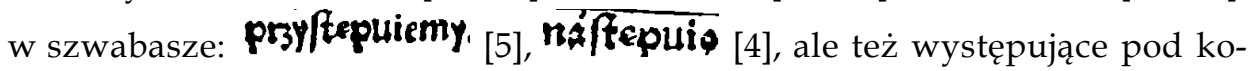
niec książki Soffempuie [347]. Świadczą one o tym, że pisownia nie była wówczas ustalona. Rozłożenie nosowości na samogłoskę ustną i spółgłoskę nosową przed spółgłoskami zwarto-wybuchowymi jest charakterystyczne dla zapisów z listu dedykacyjnego, ale sporadycznie mogło wystąpić także w głównej części

\footnotetext{
10 Szwabachy i kursywy używano głównie jako pism tekstowych, a nie nagłówkowych, w wyniku czego dłuższe fragmenty złożone wielkimi literami, zawierające majuskulne $a$ nie wystąpiły.

${ }^{11} \mathrm{~W}$ tekście nie wystąpiło złożone antykwą śródgłosowe ę.

12 Takich analogii nie udało się znaleźć w tekście zapisanym antykwą.
} 
książki, o czym świadczy pisownia słowa Jofłempuie . W tekście głównym częściej używano do zapisu głoski $\ell$ przed spółgłoską zwarto-wybuchową litery e. Nie należy wiązać takich tendencji z rodzajem pisma użytego do druku, ponieważ zarówno kursywa, jak i antykwa dysponowały czcionkami odpowiednimi dla samogłosek nosowych. Różnice w pisowni mogą natomiast świadczyć o różnym zakresie ingerencji korektora i zecera w poszczególne części rękopisu, który trafił do drukarni od tłumacza ${ }^{13}$, zagadnienie to wymagałoby jednak bardziej szczegółowych badań.

Zdarzają się też uzasadnione etymologicznie zapisy typu: miedjy [1], miedzy $[4 \mathrm{nlb} \text {. }]^{14}$. Są one w badanej próbie tekstowej nieliczne, ale konsekwentne. Czasami brak znaku diakrytycznego wynikał najprawdopodobniej z pomyłki zecera, jak np. w zapisie fie [2]. Interpretowanie takich zapisów jako błędów drukarskich wynika z ich bardzo małej frekwencji w tekście.

Niestety słaba jakość odbicia utrudnia niekiedy stwierdzenie, czy drukarz użył do oddania samogłoski nosowej czcionki $a$ czy $a$ lub $e$ czy $e$. Trudności te zależą w pewnym stopniu od rodzaju pisma, jakiego użyto do składu tekstu. Znaki diakrytyczne w postaci ukośnych kreseczek charakterystyczne dla kursywnego i antykwowego $a(\boldsymbol{z})$, a także $a$ i $\ell$ występujących w szwabasze $(\boldsymbol{E})$ są niezbyt wyraziste i bardziej podatne na zniekształcenia powstające na skutek rozlewania się farby drukarskiej lub użycia papieru niezbyt dobrej jakości. Natomiast znaki diakrytyczne w formie ogonka na dole litery, w które była zaopatrywana litera $e$ kursywna i antykwowa $(\boldsymbol{\varepsilon}, \boldsymbol{\varepsilon})$ są bardzo dobrze widoczne [Staniszewski 1960: 120-164] ${ }^{15}$. W związku z tym można stwierdzić, że trudności $\mathrm{w}$ odczytaniu wynikają $\mathrm{z}$ budowy litery $\mathrm{w}$ poszczególnych rodzajach pism. Wielkie litery, których przykłady znalazłam we fragmentach tekstu złożonych antykwą posiadały diakryty w postaci ukośnych kreseczek, tj. E - ukośna kre-

\footnotetext{
${ }^{13} \mathrm{Na}$ zróżnicowanie zakresu ingerencji drukarza w tekst autorski ze względu na część utworu zwracali uwagę Władysław Kuraszkiewicz [1960: 113-360], Jolanta Migdał [1999: 17-18] i Marek Osiewicz [2013: 33-38].

14 Słowo to nie zostało zapisane antykwą.

15 Na temat wpływu czcionki, farby drukarskiej i papieru na czytelność tekstu zob. np. Z. Staniszewski [1960: 120-164].
} 
ska przecinająca dolną poprzeczkę, A - ukośna kreska przecinająca prawą laskę, co nie utrudniało odróżnienia ich od znaków samogłosek ustnych, nawet gdy odbicie nie było najlepszej jakości ${ }^{16}$.

\section{Zapis samogłosek $i, y$}

Zasada używania do zapisu nagłosowego $i$ - znaku $i$ ukształtowała się ok. 1530 roku [Kamińska 1953: 13]. Wydany 100 lat później Słonecznik stosuje się do tej reguły, a rodzaj pisma, jakiego użyto do składu, nie odgrywa tu żadnej roli

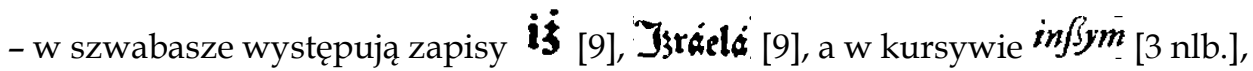
Idżie [3 nlb.] ${ }^{17}$. Jak widać w przytoczonych przykładach, zarówno szwabacha, jak i kursywa zawierają odpowiednią majuskułę i minuskułę.

Głoska $i$ występująca w śródgłosie jest również realizowana graficznie jako $i$, np. 3ginqi் [1], totriem [2]18, świáká [3 nlb.], kwieciem [3 nlb.], Słonecznikiem [3 nlb.], R O Z D Z I A L [1]. Od tej reguły nie ma wyjątków związanych z wielkością liter i rodzajem użytego pisma ani też z otoczeniem samogłoski $i$.

Identycznie oznaczane jest wygłosowe $i$, np. Oni [2], rojmáitemi [2], ći [4 nlb.], moli [4 nlb.], woli [1]. Sposób zapisu jest tu niezależny od rodzaju użytego pisma.

Książek-Bryłowa zauważa, że w drukach lubelskich $i$ występuje w dzisiejszej funkcji [1976: 341]. Wyniki moich badań pozwalają dodać stwierdzenie, że rodzaj zastosowanego pisma nie miał wpływu na pisownię samogłoski $i$.

Niezgodny z obowiązującą dziś, ale typowy dla XVII wieku (ukształtowany w poprzednim stuleciu) jest sposób oznaczania spójnika $i$, który zawsze ma formę znaku y, np. $\mathbf{}$ Doftory/ $\$$ prsplaciele [1], madrze y nabuźnie [3 nlb], O iudzkiey woli do Boskiey fpoßobieniu y pożytkách. [105] [Kamińska 1953: 15; Książek-Bryłowa 1976: 341; Bajerowa, Wieczorkowa 1989: 13; Burzywoda 2002: 31].

\footnotetext{
16 O niezbyt wyraźnych znakach samogłosek nosowych pisze Książek-Bryłowa [1976: 343]. Obecnie ułatwieniem w ustalaniu prawidłowego zapisu jest możliwość korzystania z wersji cyfrowej starodruku, która umożliwia wielokrotne powiększanie wybranych fragmentów. Niestety również ten sposób nie zawsze daje oczekiwane rezultaty.

$17 \mathrm{~W}$ tekście napisanym antykwą nie ma przykładów $i$ w nagłosie.

${ }^{18} \mathrm{~W}$ tekście złożonym szwabachą brak przykładów majuskulnego $i$ w śródgłosie.
} 
W analizowanej próbie materiałowej nie znalazłam przypadków mieszania i z y, choć w XVII stuleciu mogły się one zdarzać [Burzywoda 2002: 29-30]. Graficzne oznaczenia samogłoski $y$ występują w szwabasze, kursywie i antykwie, np. wjorygat [4], Doftory [1], názynamy. [3 nlb.], w/sechmogacy [2 nlb.], KATHARZYNIE [3 nlb.]. Niezależnie od otoczenia i pozycji do zapisu jest stosowany znak $y$, co zgadza się z zasadami ukształtowanymi jeszcze w poprzednim stuleciu [por. Kamińska 1953: 14-15].

Na marginesie należy dodać, że tymi samymi znakami, co samogłoski $i$ oraz $y$ jest oznaczane $j^{19}$. ponieważ $\mathrm{w}$ analizowanym starodruku nie ma osobnego

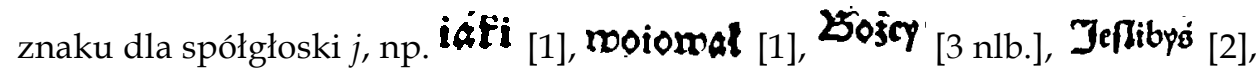
froónicýfego [5], mieycie [5], ia [3 nlb.], moie [5 nlb.], fwoy [3 nlb.], Iako [22], rayskryt/se [22], Ludzkiey [1 nlb.], POLSKIEY [3 nlb.], IER EMIASZ $[1 \mathrm{nlb} .]^{20}$. Jak widać na podstawie powyższych przykładów, głoska $j$ w nagłosie i śródgłosie przed samogłoską była oznaczana grafemem $i$. W śródgłosie przed spółgłoską i w wygłosie spółgłoskę j zapisywano przy pomocy grafemem y (bez względu na rodzaj pisma i wielkość liter).

\section{Graficzne oznaczenia samogłoski $u$}

Krystyna Kamińska [1953: 19-20] stwierdza, że w XVI wieku ukształtowała się norma zapisywania nagłosowego $u$ jako $v$, a śródgłosowego i wygłosowego jako u. Bajerowa i Wieczorkowa [1989: 12] zauważają, że XVII stulecie było okresem, w którym udoskonalił się zapis samogłoski $u$, ponieważ pod koniec wieku zaczął zanikać zwyczaj zapisywania nagłosowego $u$ przy pomocy litery $v$. Tezę o dokonaniu się zmiany normy graficznej potwierdza też Burzywoda [2002: 32-33]. W pierwszym druku Pawła Konrada nie można zaobserwować takich tendencji, ponieważ samogłoska $u$ jest zapisywana w postaci dwóch liter, tzn. jako $v$ lub $u$. Zasadniczo kontynuuje się zwyczaj XVI-wieczny: $v$ pojawia się w nagłosie, np. opatroxáli [1], vtrapionym. [5 nlb. $]^{21}$, a $u$ w śródgłosie i w wygłosie, np. erunfu [1], Tamiotu [1]; rozumne [4 nlb.], W fchods [3 nlb.]; iudzkiey [49],

\footnotetext{
${ }^{19}$ Sposób graficznego oznaczania spółgłoski j nie jest przedmiotem artykułu, jednak ściśle wiąże się z zagadnieniem użycia liter $i$ oraz y. $Z$ tych względów poświęcam uwagę temu zagadnieniu. 20 Tekst złożony antykwą nie zawiera innych przykładów.

${ }^{21}$ Brak odpowiednich przykładów w tekście złożonym antykwą.
} 
póznániu [1]. Rodzaj użytego pisma zasadniczo nie wpływał na realizację omawianej zasady. Wyjątki od reguły stanowią zapisy słów $L V B L I N I E$ [1 nlb.] i N A VKA [33], świadczące o tym, że śródgłos wyrazu złożonego wielkimi literami kursywy i antykwy mógł zawierać zapis głoski $u$ w postaci grafemu $v$.

W lubelskim wydaniu Słonecznika wykorzystano trzy rodzaje pisma drukowanego: szwabachę, kursywę i antykwę. We fragmentach złożonych wymienionymi rodzajami pisma zaznaczają się zarówno ortograficzne tendencje unifikujące, jak i dyferencjujące.

Unifikacja zaznaczyła się w zapisie samogłosek pochylonych. Czcionki minuskulne służące do oznaczania pochylonego $e$ oraz $o$ nie były w żadnym rodzaju pisma zaopatrzone w znaki diakrytyczne. Minuskulna czcionka służąca do zapisania $a$ jasnego posiadała niezależnie od rodzaju pisma diakryt. Nad literami majuskulnymi nie występowały żadne dodatkowe oznaczenia, co wynikało z ograniczeń technicznych. W związku z tym we fragmentach zapisanych wielkimi literami nie rozróżniano samogłosek jasnych i pochylonych.

Tendencje unifikujące obserwować można również w odniesieniu do zapisów samogłosek $i$ oraz y. Szwabacha, kursywa i antykwa zawierały odpowiednie czcionki do ich składu (tak minuskulne jak majuskulne). Pozwalało to Pawłowi Konradowi na przestrzeganie obowiązujących w epoce zwyczajów graficznych, dotyczących nie tylko zapisu samogłosek $i$ oraz $y$, lecz również oznaczania przy pomocy grafemów $i$-y spółgłoski $j$.

Pewne zróżnicowanie ortografii starodruku, wynikające z wyboru określonego rodzaju pisma, jest widoczne w odniesieniu do samogłosek nosowych oraz samogłoski $u$. Małe litery odnoszące się do samogłosek nosowych były w każdym z pism zaopatrzone w znaki diakrytyczne w postaci kreseczek lub ogonków. Duże litery nie zawsze takie znaki posiadały.

Samogłoska $u$ była zapisywana przy pomocy majuskulnego grafemu $u$ lub $v$ w zależności od jej miejsca w nagłosie, śródgłosie lub wygłosie wyrazu. Było to niezależne od rodzaju użytego pisma. Jeśli w zapisach występowały wielkie litery, we fragmentach złożonych antykwą i kursywą w śródgłosie występował grafem $v$ (w zapisach małymi literami zawsze $w$ tej pozycji występował grafem $u$ ). Może to sugerować, że drukarz nie dysponował odpowiednią ilością czcionek z majuskułą $u$. 
Daje się zauważyć, że zasób typograficzny używany w drukarni Pawła Konrada był w znacznym stopniu przystosowany do fonetyki ówczesnego języka polskiego. Różnice w zapisie samogłosek wynikające z wyboru konkretnego rodzaju pisma nie były znaczne. Większą rolę odgrywał w ortografii skład wielkimi lub małymi literami poszczególnych pism.

Różnice w pisowni nie zawsze dają się wyjaśnić zastosowaniem określonego pisma drukowanego lub wyborem małych lub wielkich liter. Dyferencjacja ortografii mogła być spowodowana odmiennym sposobem składu poszczególnych partii dzieła. Być może wynikała też ze zmiennego stopnia ingerencji drukarza w poszczególne fragmenty tekstu autorskiego. Przykładem mogą tu być zapisy wyrazów zawierających samogłoskę e przed spółgłoską zwarto-wybuchową z listu dedykacyjnego i tekstu zasadniczego. Niekiedy odstępstwa od dominującej tendencji wynikały z pomyłki zecera.

Obserwacja różnych typów pisma w tekstach z epoki średniopolskiej pozwala nie tylko rekonstruować normalizację ortografii w starodrukach, ale daje też wgląd w ówczesne procesy ewolucyjne w fonetyce języka polskiego.

\section{Bibliografia}

\section{Źródła}

DreXeliUs J., 1630: Stonecznik Albo Porownanie Woli Ludzkiey z wola Boża [on-line], Lublin: Paweł Konrad (dostęp 19.06.2013). Dostępny w: http://dlibra.umcs.lublin.pl/dlibra/doccontent?id=400\&from=FBC.

\section{Opracowania}

BAJEROWA I., WIECZORKOWA A., 1989: Uwagi o pisowni druków XVII-wiecznych, „Prace naukowe Uniwersytetu Śląskiego. Prace językoznawcze”, nr 17, "Studia historycznojęzykowe”, s. 9-22.

BurZYWODA U., 2002, Grafia i ortografia, w: Polszczyzna XVII wieku. Stan i przeobrażenia, red. D. Ostaszewska, Katowice: Wydawnictwo Naukowe Śląsk, s. 27-40. DZIOK-STRELNIK I., 1997: Bibliografia starych druków lubelskich 1630-1800, Lublin: Wojewódzka Biblioteka Publiczna im. H. Łopacińskiego w Lublinie.

ESTREICHER K., 1897: Bibliografia polska, cz. 3, t. 4 (15), Kraków: Akademia Umiejętności, s. 315-318. 
GRZEBIEŃ L., 1985: Drexel, Drexelius Jeremias, hasło w: Encyklopedia katolicka, t. 4, red. R. Łukaszyk, L. Bieńkowski, F. Gryglewicz, Lublin: Towarzystwo Naukowe Katolickiego Uniwersytetu Lubelskiego, coll. 209.

JODŁOWSKI S., 1979: Losy polskiej ortografii, Warszawa: Państwowe Wydawnictwo Naukowe.

JudA M., 2000: Konrad Pawet, hasło w: Drukarze dawnej Polski od XV do XVIII wieku, t. 1 Małopolska, cz. 1 Wiek XVII-XVIII, vol. 1 A-K, red. J. Pirożyński, Kraków: Polska Akademia Umiejętności, s. 332-336.

JudA M., 2001: Pismo drukowane w Polsce XV-XVI wieku, Lublin: Wydawnictwo Uniwersytetu Marii Curie-Skłodowskiej.

KAMIŃSKA K., 1953: Pisownia druków polskich XVI wieku, „Prace Polonistyczne", t. 11, s. 5-28.

KEMPER H.-G., 1985: Literarischer Glaubenskampf, w: Deutsche Literatur. Eine Sozialgeschichte, t. 3, Zwischen Gegenreformation und Frühaufklärung: Späthumanismus, Barock 1572-1740, red. H. Steinhagen, Reinbeck bei Hamburg: Rowohlt, s. 139-171.

KSIĄŻEK-BRYŁOWA W., 1976: O języku druków lubelskich z XVII wieku, „Annales Universitatis Mariae Curie-Skłodowska", Sectio F, vol. XXXI, s. 337-355.

KurASzKIEWICZ W., 1960: Szkice o jezzyku Mikołaja Reja, w: Odrodzenie w Polsce. Materiaty z sesji naukowej PAN 25-30 października 1953 roku, t. 3, Historia języka, cz. 1, red. M.R. Mayenowa, Z. Klemensiewicz, Warszawa: Państwowy Instytut Wydawniczy, s. 113-360.

LEWICKA-KAMIŃSKA A., 1976: Zagadka drukarza „Kazañ" papieża Leona I (tzw. Typographus Leonis I Papae: „,Sermones”), „Roczniki Biblioteczne”, R. XX, z. 3-4, s. 495-561.

LISOWSKI T., 2001: Grafia druków polskich z 1521 i 1523 roku. Problemy wariantywności i normalizacji, Poznań: Wydawnictwo Naukowe Uniwersytetu im. Adama Mickiewicza w Poznaniu.

LUTO-KAMIŃSKA A., 2012: O czytaniu i odczytaniu dzieł literatury staropolskiej. Czy jezzykoznawca czyta inaczej?, „Linguistica Copernicana”, nr 2 (8), s. 51-64.

MigdaŁ J., 1999: O jezzyku Andrzeja Glabera z Kobylina. Studium normalizacji polszczyzny wczesnorenesansowej, Poznań: Wydawnictwo WiS.

OsIEWICZ M., 2013: Wariantywność graficzna Ksiąg o gospodarstwie Piotra Krescentyna z 1549 roku. Studium przypadku, Poznań: Wydawnictwo Rys.

PIROŻYŃSKI J., 2002: Johannes Gutenberg i początki ery druku, Warszawa: Wydawnictwo Naukowe PWN. 
PrZyboś A., ŻELEWSKi R.: 1980, Wstęp, w: A.S. Radziwiłł, Pamiętnik o dziejach w Polsce, przełożyli i opracowali A. Przyboś, R. Żelewski, t. 1, Warszawa: Państwowy Instytut Wydawniczy, s. 5-86.

STANISZEWSKI Z., 1960: Estetyka polskiego druku książkowego XVIII w. Zarys problematyki, "Ze skarbca kultury", z. 1 (12), s. 120-164.

SZANDOROWSKA E., 1968: Czy w Chetmnie nad Wista drukowano inkunabuty?, „Rocznik Biblioteki Narodowej", t. 4, s. 23-49.

SZANDOROWSKA E., 1991: Jeszcze raz w sprawie "Drukarza Kazań papieża Leona I", w: Z badań nad dawna ksiązką. Studia ofiarowane profesor Alodii KaweckiejGryczowej w 85-lecie urodzin, t. 1, red. P. Buchwald-Pelcowa, Warszawa: Biblioteka Narodowa.

TORÓJ E., 1997: Inwentarze księgozbiorów mieszczan lubelskich z lat 1591-1678, Lublin: Wydawnictwo Uniwersytetu Marii Curie-Skłodowskiej.

VALENTIN J.-M., 1985: Jesuiten-Literatur als gegenreformatorische Propaganda, w: Deutsche Literatur. Eine Sozialgeschichte, t. 3, Zwischen Gegenreformation und Frühaufklärung: Späthumanismus, Barock 1572-1740, red. H. Steinhagen, Reinbeck bei Hamburg: Rowohlt, s. 172-205.

ŻURKOWA R., 1986: Księgozbiory mieszczan krakowskich w XVII wieku, w: Historia ksiażki i jej funkcji społecznej. Wybór tekstów naukowych dla studentów bibliotekoznawstwa i informacji naukowej, cz. 2, wybór i oprac. W. Szelińska, M. Konopka, Kraków: Wydawnictwo Naukowe WSP, s. 55-85.

\section{Oznaczenia literowe samogłosek w różnych rodzajach pisma drukowanego z XVII wieku (na podstawie Słonecznika Jeremiasza Drexeliusa) (streszczenie)}

W 1630 roku został opublikowany w Lublinie Słonecznik Jeremiasza Drexeliusa. Był on pierwszą książką wydaną przez miejscową oficynę wydawniczą, należącą wówczas do Pawła Konrada. Do składu tego tekstu zostały użyte trzy rodzaje pism drukowanych: szwabacha, kursywa i antykwa. Artykuł przedstawia sposoby zapisu samogłosek we fragmentach tekstu złożonych tymi pismami, które dokumentują wariantywność i normalizację ówczesnej ortografii. 